Document downloaded from:

http://hdl.handle.net/10251/156855

This paper must be cited as:

Ribes-Giner, G.; Moya Clemente, I.; Cervelló Royo, RE.; Perelló Marín, MR. (2019). Wellbeing indicators affecting female entrepreneurship in OECD countries. Quality \& Quantity. 53(2):915-933. https://doi.org/10.1007/s11135-018-0796-4

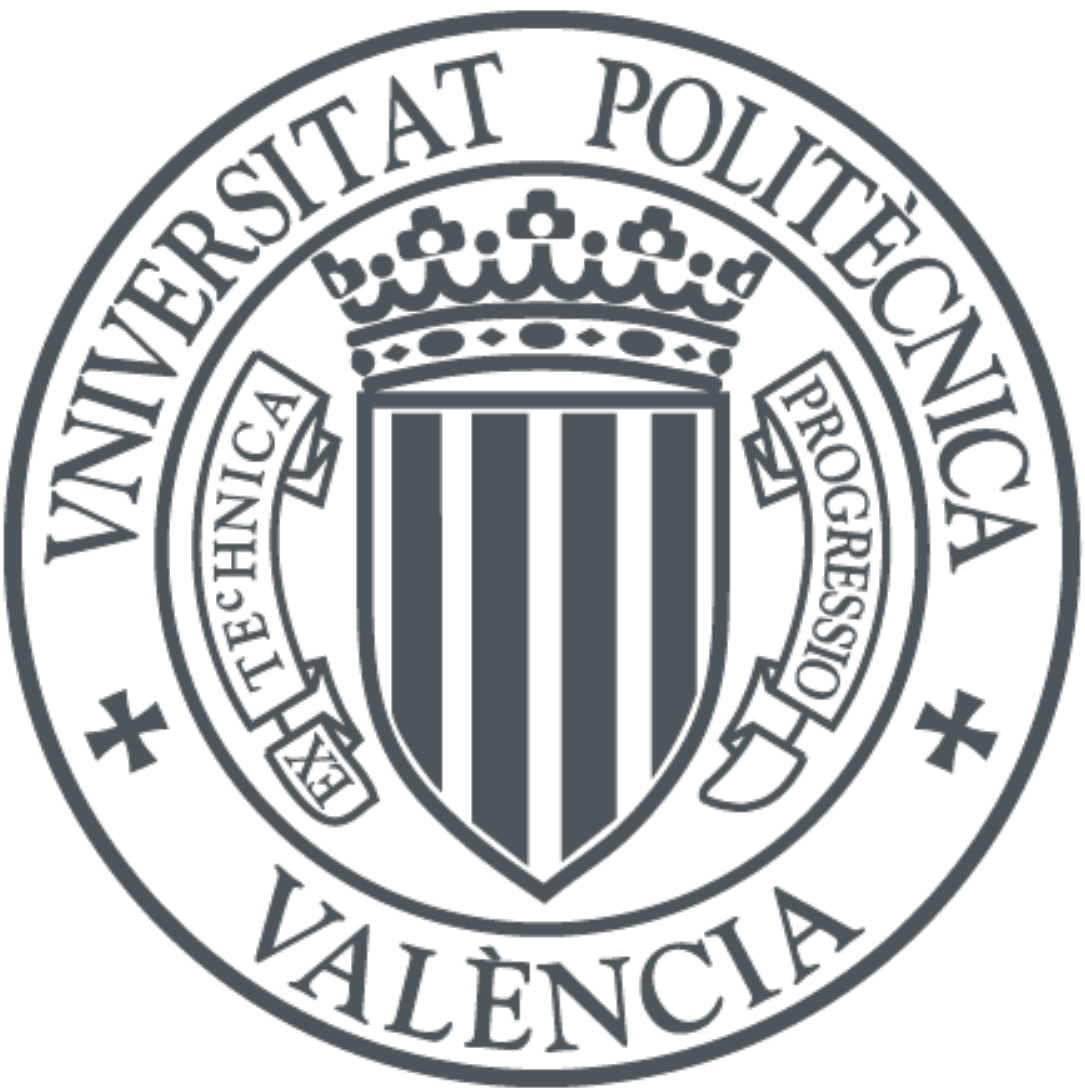

The final publication is available at

https://doi.org/10.1007/s11135-018-0796-4

Copyright Springer-Verlag

Additional Information 


\title{
Wellbeing indicators affecting female entrepreneurship in OECD countries
}

\author{
Ribes-Giner, G.; Moya-Clemente, I.; Cervelló-Royo*, R.; Perello-Marin, M. R. \\ Faculty of Business Administration and Management, Building 7J, Universitat \\ Politècnica de València, camino de vera $s / n, 46022$ \\ *corresponding author: rocerro@esp.upv.es
}

\begin{abstract}
The objective of this research is to know which wellbeing indicators, such as work-life balance, educational level, income or job security, are related to the rate of female entrepreneurship in 29 OECD countries. In addition, these countries have been classified according to the motivation of the entrepreneur either by necessity or by opportunity.

The empiric study is focused on 29 OECD countries covering the different geographic areas (Western Europe, Central and Eastern Europe, Middle East, etc.) Due to the fact that the sample is relatively small, it is essential to use a selective approach when selecting the causal conditions. To this end, fsQCA is the most appropriate methodology for such a small data set. A total of 5 variables have been used: an independent variable (female TEA ratio), and four dependent variables (work life balance, educational level, sustainable household income and job security). Data measuring female TEA ratio have been obtained from Global Entrepreneur Monitor (GEM, 2015) data base, while data measuring wellbeing dimensions were taken from the Better Life Index (OECD, 2015). The results of this piece of research show that countries with high sustainable household income together with high level of education achieves high female entrepreneurship ratio with both, a good work-life balance (despite of a high unemployment probability), or a high labour-personal imbalance (in this latter, with a low probability of unemployment).
\end{abstract}


Keywords: wellbeing, female entrepreneurship, gender, FsQCA, work-life balance

JEL CODES: 131, M130, 0570

\section{Acknowledgements}

This work has been funded by the R+D project for emerging research groups with reference (GVA) GV/2016/078. 


\title{
Wellbeing indicators affecting female entrepreneurship in OECD countries
}

\author{
ABSTRACT \\ The objective of this research is to know which wellbeing indicators, such as work-life balance, educational \\ level, income or job security, are related to the rate of female entrepreneurship in 29 OECD countries. In \\ addition, these countries have been classified according to the motivation of the entrepreneur either by \\ necessity or by opportunity.
}

The empiric study is focused on 29 OECD countries covering the different geographic areas (Western Europe, Central and Eastern Europe, Middle East, etc.) Due to the fact that the sample is relatively small, it is essential to use a selective approach when selecting the causal conditions. To this end, fsQCA is the most appropriate methodology for such a small data set. A total of 5 variables have been used: an independent variable (female TEA ratio), and four dependent variables (work life balance, educational level, sustainable household income and job security). Data measuring female TEA ratio have been obtained from Global Entrepreneur Monitor (GEM, 2015) data base, while data measuring wellbeing dimensions were taken from the Better Life Index (OECD, 2015). The results of this piece of research show that countries with high sustainable household income together with high level of education achieves high female entrepreneurship ratio with both, a good work-life balance (despite of a high unemployment probability), or a high labour-personal imbalance (in this latter, with a low probability of unemployment).

Keywords: wellbeing, female entrepreneurship, gender, FsQCA, work-life balance

JEL CODES: I31, M130, O570

\section{Introduction}

Entrepreneurship and wellbeing are different concepts which share some aspects. In fact, it has been found the process of enterprising is closely associated with wellbeing (Parasuraman, et al., 1996; Shir, 2015). However, there is still very little known about the relationship between entrepreneurship and wellbeing (Uy, Foo, \& Song, 2013). 
Although research in wellbeing has been growing in recent decades, the question of how it should be defined still remains unanswered (Dodge et al., 2012; Murias et al., 2006). It is an intangible concept, difficult to define and even harder to measure (La Placa et al., 2013; Ng \& Feldman, 2009). Wellbeing is usually referred to as an individual's perceptions and evaluation of life (Chaaban et al., 2016; La Placa et al., 2013). It has been studied from various points of view, such as economic wellbeing or subjective wellbeing. Moreover, wellbeing has objective and subjective components that should be taken into account together (La Placa et al., 2013; Maccagnan et al., 2018) in order to undertake a detailed and comprehensive analysis.

Focusing on wellbeing of employees in business organisations, subjective wellbeing corresponds to their self-fulfilment (La Placa et al., 2013). It is usually analysed through quality of life, life satisfaction, job satisfaction and happiness (Harter et al., 2003; Diener, 2009). It is probably, the most analysed perspective within this context,(Rahman et al. , 2016; Sampedro et al., 2007). Furthermore, economic wellbeing has been traditionally related to economic growth variables that include either income or per capita GDP (Murias et al., 2006). This perspective is one of the most commonly used related to entrepreneurs (Carter 2011). Due to this lack of consensus over how to measure wellbeing, amongst the possible ways to measure it, OECD wellbeing indicators have been used along this piece of research as a basis for the analysis of the aforementioned relationship (Boarini \& D'Ercole, 2013). Particularly, variables from the Better Life index (BLI) have been used (Chaaban et al., 2016)

On the other hand, research on entrepreneurship has been growing too (D. A. Shepherd et al, 2000). An entrepreneur is known as a person who sets up a business or businesses, taking on financial risks in the hope of achieving profit. Entrepreneurial activity is a social process involving the efforts of individuals in enterprise activity (O’Connor, 2013). There are different motivations to undertake an entrepreneur venture. Considering the Global Entrepreneurship Monitor (GEM) as definition of motivation, (Hessels et al., 2008; Levie \& Autio, 2008; Reynolds et al., 2002) two different types of motivation can be distinguished: necessity and opportunity entrepreneurship. Where necessity driven entrepreneur are those who claim not having other option for work as opposed to finding better opportunities such us increasing their incomes, or being independent. The factors influencing entrepreneurs could be different depending on the underlying motivation (Kirkwood, 2009; Verheul et al., 2006). On the other hand, monetary (as for instance, income) and non-monetary (such as quality of life) components that stimulate entrepreneurship can also be found (Kautonen et al., 2017). 
It has been argued that entrepreneurs usually have greater freedom, flexibility, and opportunity to achieve self-fulfilment (Parasuraman \& Simmers 2001) which are aspects included in the prior definition of wellbeing (seen as quality of life attributes). However, little is still known about the relationship between entrepreneurship and wellbeing (Uy et al., 2013).

Although very little work has been already carried out on analysing the relationship between entrepreneurs and wellbeing, there are still a few pieces of work that provide interesting hints. For instance, Berglund (2015) described entrepreneurs and their behaviours. This piece of research shows how they struggle to achieve certain degree of wellbeing through entrepreneur activities. Uy et al (2017) examined the relationship between affect fluctuations and goal orientation on psychological wellbeing within an earlystage population of entrepreneurs. Shepherd \& Haynie (2009) studied entrepreneurs and their ability to find their wellbeing balance in terms of identity and distinctiveness (psychological wellbeing). Andersson (2008) analysed differences in wellbeing between wage-earners and the self-employed (considered as entrepreneurs) regarding non-pecuniary aspects of their occupation including not only job satisfaction and life satisfaction but also perceptions of the job as mentally straining and stressful, mental health, and general health. He found that the self-employed are more satisfied with their jobs, however, there were also indications that self-employment increases mental health problems, in particular, tiredness. But despite all these pieces of research, there are not enough hints to be able to clearly assert that there is a real relationship between entrepreneurship and wellbeing, and to what extent, in clear and specific terms

On the other hand, when analysing wellbeing, it is also found that it is an especially relevant issue for women, particularly when it comes to setting up a new business (Ahl \& Nelson, 2015; Cervelló-Royo et al. 2015, 2017; Henry et al., 2015;).

It has also been also seen that although entrepreneurship is becoming an increasingly important source of employment for women across many countries, the level of female involvement in entrepreneurial activity, however, is still significantly lower than that of men (Langowitz \& Minniti, 2007; Tur-Porcar et al. 2017; Ribes-Giner et al. 2018). Although there are a small number of studies dealing with women and wellbeing (Iezzi and Deriu, 2014; Castellano et al. 2017), the relationship between female entrepreneurship and wellbeing is not being analysed in depth yet. For instance, Bianchi et al (2016) identify the constraints that women might face in becoming entrepreneurs and correlate them with the motivations that have determined 
this choice and the fulfilled wellbeing. However, it can be argued that to date a clear relationship between both concepts, female entrepreneurship and wellbeing, has not been proven yet.

Within this piece of research, comparisons between OECD countries in terms of female entrepreneurship and wellbeing performance have been carried out. It showed that there is an increasing interest in carrying out cross-country comparisons to test their situation not only in terms of political and economic aspects but also regarding their wellbeing indicators, but none of the previous studies have specifically considered the gender factor.

In this vein, several studies have already been carried out to assess how wellbeing is changing over time and/or compares across OECD countries (Bardasi et al, 2011; Bergheim et al, 2006; Boarini et al, 2012; Boarini \& D’Ercole, 2013; Kobeissi, 2010; Poggesi et al, 2015; Verheul et al., 2006). Most of those studies mainly assess whether economic indicators, like Gross Domestic Product (GDP), etc. are adequate proxies as a measure of wellbeing. In fact, many of those studies criticise the fact that attention is limited to only some factors while other elements which also influence wellbeing such as the environment, home production and non-market factors are not taken into account. For example, the OECD's Going for Growth publication focuses on policies that have the potential to improve economic performance as measured by GDP per capita. As Kuckertz et al. (2015) suggest, the use of Economic Growth and/or GDP per capita indicators to study the relationship between entrepreneurship activity and the level of satisfaction in a society is incomplete, since they do not consider social issues. These economic indicators usually fail when analysing a society and other alternative and more appropriate social measures should be considered (Naude et al. 2014).

Thus, despite indicators related to economic growth remain critical for any assessment of wellbeing, they should be complemented with measures of other wellbeing indicators like: household incomes (Cummins et al., 2003; Kautonen et al., 2017), longevity (Osberg \& Sharpe, 2002, 2009), employment (Fleche et al, 2012), work-life balance (Andersson, 2008), child wellbeing, sole-parent family structures, health, social cohesion, other social indicators, etc. (Bradshaw et al., 2007; Boarini \& D'Ercole, 2013; Chapple, 2009). In this line of argument, Osberg \& Sharpe (2009) introduce a new estimate of the Index of Economic Wellbeing (IEWB) for 14 OECD countries during the period 1980-2007. In this index, they consider complementary aspects like leisure and longevity. However, they state that other aspects like educational attainment, housing expenditure, etc. could also be addressed. That is the main reason why, in the present 
study, we decided to focus on the Better Life Index (OECD, 2013, 2015) for 29 OECD countries, since it considers not only income indicators but also other wellbeing dimensions/indicators like Housing, Jobs, Community, Education, Health and Work-Life Balance (Chaaban et al., 2016). Moreover, we chose to use FsQCA methodology because it allowed us to work with this small size data set.

The objective of this research is to know which wellbeing indicators, such as work-life balance, educational level, income and job security, are related to the rate of female entrepreneurship in 29 OECD countries. In addition, these countries will be classified according to the motivation of the enterprise either by necessity or by chance.

The remainder of the paper is organised as follows. In Section 2 earlier research is summarised and hypothesis are set, in Section 3 material and methods are described, and in Section 4 data sets are described. In Section 5 the results and discussion are presented, and Section 6 concludes the paper.

\section{Theoretical Background and Hypothesis}

As it has been described above, the main purpose of this paper is to study the relationship between the female/male tea ratio as a measure of female entrepreneurship in a country and the wellbeing of each country. As a measure of the wellbeing, four indicators have been chosen from the Better life Index (OECD 2013, 2015): work life balance, educational attainment, income and jobs security; due to the fact that they are directly linked to the wellbeing of a country (Boarini \& D'Ercole, 2013; Chaaban et al., 2016).

Four hypothesis have been stablished taking these into account

\section{Worklife balance}

A number of family-related factors have been found to be important in entrepreneurship literature, such as combining waged and domestic labour and a desire for work-family balance (Brindley, 2005). Although family related motivations for becoming an entrepreneur are often labelled push factors and have been recently described as important to entrepreneurs of both genders around the world, these household and family issues are recently being recognised as significant to explaining women's entrepreneurship (Kirkwood, 2009; Patrick et al., 2016; Ruth Eikhof et al., 2013; Saridakis et al., 2014).

\section{Proposition 1. Female entrepreneurship relates to work-life balance}




\section{Educational attainment}

It is consistently found that entrepreneurs in developed countries exhibit higher rates of success when they have higher levels of education (Foley \& Griffith, 1998; Johansen \& Foss, 2013; Leffler \& Svedberg, 2005; Martin et al., 2013; Orlova et al., 2016; Van der Sluis et al., 2008; Shinnar et al., 2014) and even more so when this education is combined with experience (O’Connor, 2013).

Minniti \& Nardone (2007) reported a relationship between higher levels of education attainment and startup business activities generally among those nations contributing to the Global Entrepreneurship Monitor study. In particular, it has also been found that higher education levels reduce capital constraints for a new venture, which in turn influences a firm's performance (Van der Sluis et al., 2008).

It is important to highlight that higher levels of general education attainment are more common among entrepreneurs than entrepreneurship education specifically (O'Connor, 2013). However, there are only a few studies dealing with the influence of educational attainment in female entrepreneurship (Brindley, 2005; Buttner \& Moore, 1997; Kephart \& Schumacher, 2005; Kobeissi, 2010; McClelland, Swail, Bell, \& Ibbotson, 2005).

\section{Proposition 2. Female entrepreneurship is linked to Educational attainment}

Income.

Several studies on wellbeing consider income as major factor (Cumming et al., 2016; Cummins et al., 2003; Mishra et al., 2014). However, some authors revise and propose the inclusion and consideration of other labour market components as complementary to the first one (Osberg \& Sharpe, 2009).

Nevertheless, there is a strong link between household income and the entrepreneurship activity of a country (Kautonen et al., 2017). As it can be checked, there is abundant literature in which several authors relate income and/or household incomes with the entrepreneurship activity of a country both for better or worse (Andersson, 2008; Bittencourt Marconatto et al., 2016; Castaño et al., 2015; Woodside et al., 2015). Furthermore, some of these studies go in depth in this entrepreneurship-income relationship and provide a gender-based approach (de la Cruz Sánchez-Escobedo et al., 2014), focusing mainly on female entrepreneurship (Christofides et al., 2013; Garikipati, 2012; Torri \& Martinez, 2014; Witbooi \& Ukpere, 2011). 
Proposition 3. Female entrepreneurship is related to Income.

\section{Jobs Security (percentage)}

As we have previously stated, besides income, several studies recommend the inclusion of other household components. Based on self-reported life satisfaction surveys, Fleche et al. (2011), show how, apart from income, other indicators like not being unemployed and social relationships are very important for wellbeing with few differences across OECD countries. Several studies consider employment indicators like jobs security (Jansson, 2017; Renee Baptiste, 2008) as indicators of strong influence over wellbeing. Osberg \& Sharpe (2009), propose several wellbeing indicators for selected OECD countries, considering not only household income and expenditure aspects but also those related to job security and or employment/unemployment. Regarding entrepreneurship, several authors state there is a strong link between jobs security (employment/unemployment) and a country's entrepreneurship activity (Burke et al., 2008; Jansson, 2017; Kautonen et al., 2017; Millán et al., 2013). Moreover, some authors go in depth in this job security-entrepreneurship relationship and provide a gender approach (de la Cruz SánchezEscobedo et al., 2014; Kautonen et al., 2017) emphasising the role played by female entrepreneurship (Christofides et al., 2013; Torri \& Martinez, 2014).

\section{Proposition 4. Female entrepreneurship related to Job Security (percentage)}

\section{Material and Methods}

Fuzzy set qualitative comparative analysis (FsQCA) is an empiric method based on Boolean algebra that allows for a configurational examination of the causal relationship between a group of antecedent conditions and a related outcome (Ragin, 1989, 2000), this methodology offers a set theoretic approach to causality analysis, in respect of conditions and an outcome (Ragin, 2008). This method acknowledges that different combinations might explain an outcome, in other words, different combinations of attributions might explain the same outcome. It has recently been used in the context of entrepreneurship (Judge et al., 2015; Kuckertz et al., 2015; Mandl et al., 2016; Rey-Martí et al., 2015).

The study observes which wellbeing motives such as work life balance, educational attainment, income and job security have a relationship with female entrepreneurship. Since our sample is relatively small, 29 OECD countries, it is critical to use a selective approach when choosing causal conditions. While traditional 
variance methods require a normal probability distribution of variables, FsQCA is more suitable for smaller samples such as the one researched in this paper. As stated by Lee (2013) in her study for 18 OECD countries, the number of countries is limited due to the availability of comparable data, however, the number of cases is sufficient for exploiting fs/QCA (Ragin 1987, 2000). Furthermore and since FsQCA does not assume any kind of probability distribution, outliers are not as much of a concern as in regression analysis (Fiss, 2011). Consequently, we used a total of five variables, one outcome (TEA ratio) and four antecedent conditions (work-life balance, educational attainment, income and job security).

The study observes how wellbeing variables have a relationship with female entrepreneurship in OECD countries (See Table 1). Currently, several authors have used the FsQCA methodology to analyse issues related to this research, to apply the fuzzy QCA methodology, Fs/QCA software v. 3.0 has been used (Thiem \& Dusa, 2013).

By applying the FsQCA methodology we study the relationship between the entrepreneurship by gender and the wellbeing conditions of a country, especially those socially related with gender from a female working labour conditions standpoint. 
Table 1. Definition of variables

\begin{tabular}{|c|c|c|c|}
\hline \multicolumn{2}{|l|}{ Conditions } & \multirow{2}{*}{$\frac{\text { Symbol }}{\text { tearatio }}$} & \multirow{2}{*}{$\begin{array}{l}\text { Items } \\
\text { Relation between Female TEA and } \\
\text { Male TEA (Female TEA divided by } \\
\text { Male TEA) }\end{array}$} \\
\hline Outcome/Results & TEA ratio (GEM 2015) & & \\
\hline \multirow[t]{4}{*}{ Antecedent Conditions } & $\begin{array}{l}\text { Employees working very } \\
\text { long hours (percentage) }\end{array}$ & work-life balance & $\begin{array}{l}\text { This indicator measures the } \\
\text { proportion of dependent employed } \\
\text { whose usual working hours per } \\
\text { week are } 50 \text { hours or more. }\end{array}$ \\
\hline & $\begin{array}{ll}\text { Education } & \text { Attaiment } \\
\text { (percentage) } & \end{array}$ & education & $\begin{array}{l}\text { Educational attainment considers } \\
\text { the number of adults aged } 25 \text { to } 64 \\
\text { holding at least an upper secondary } \\
\text { degree over the population of the } \\
\text { same age, as defined by the OECD- } \\
\text { ISCED classification }\end{array}$ \\
\hline & Income & income & $\begin{array}{l}\text { Represents the maximum amount } \\
\text { that a household can afford to } \\
\text { consume without having to reduce } \\
\text { its assets or to increase its liabilities. } \\
\text { It is obtained by adding to people's } \\
\text { gross income (earnings, self- } \\
\text { employment and capital income, as } \\
\text { well as current monetary transfers } \\
\text { received from other sectors) the } \\
\text { social transfers in-kind that } \\
\text { households receive from } \\
\text { governments (such as education and } \\
\text { health care services), and then } \\
\text { subtracting the taxes on income and } \\
\text { wealth, the social security } \\
\text { contributions paid by households as } \\
\text { well as the depreciation of capital } \\
\text { goods consumed by households. } \\
\text { Available data refer to the sum of } \\
\text { households and non-profit } \\
\text { institution serving households). }\end{array}$ \\
\hline & Job Security (percentage) & Jobs & $\begin{array}{l}\text { Job Security (percentage) This } \\
\text { indicator presents the probability to } \\
\text { become unemployed. It is } \\
\text { calculated as the number of people } \\
\text { who were unemployed in } 2013 \text {, but } \\
\text { were employed in } 2012 \text { over the } \\
\text { total number of those employed in } \\
2012 \text {. }\end{array}$ \\
\hline
\end{tabular}

Table 1 introduces the Outcome Variable/Results (TEAratio) and the Antecendent Conditions (rest of variables)

Source: authors' own elaboration from the GEM (Reynolds et al., 2002) and OECD Better Life Index (OECD, 2015) 
4 Data

This empirical study analyses 2015 data from 29 OECD countries covering different geographical areas (Western Europe, Eastern and Central Europe, the Middle East, etc.). Data has been retrieved from two databases: GEM (GEM, 2015) and OECD Better Life Index (OECD, 2015), as it can be seen in Table 2.

GEM is a trusted resource on entrepreneurship for key international organisations like the United Nations, the World Economic Forum, the World Bank, and the Organisation for Economic Cooperation and Development (OECD), providing custom datasets, special reports and expert opinion. The total early-stage entrepreneurial activity (TEA) is the GEM's most well-known index, representing the percentage of the population aged 18-64 who are either a nascent entrepreneur or owner-manager of a new business.

The other index that we used is the OECD Better Life Index (OECD, 2015), this Index allows to compare wellbeing across countries, based on 11 topics the OECD has identified as essential, in the areas of material living conditions and quality of life. 
Table 2. OECD Countries' Data.

\begin{tabular}{|c|c|c|c|c|c|}
\hline \multirow{2}{*}{$\begin{array}{c}\text { OECD } \\
\text { COUNTRY } \\
\text { NAME }\end{array}$} & \multirow{2}{*}{$\begin{array}{c}\text { FEMALE/MALE } \\
\text { TEA RATIO }\end{array}$} & \multicolumn{4}{|c|}{ WELLBEING } \\
\hline & & Income & Jobs & Education & $\begin{array}{c}\text { Work-Life } \\
\text { Balance }\end{array}$ \\
\hline Australia & 0.65 & 31588 & 4.8 & 76 & 14.02 \\
\hline Austria & 0.68 & 31173 & 3.9 & 83 & 7.61 \\
\hline Belgium & 0.67 & 28307 & 5 & 72 & 4.57 \\
\hline Great Britain & 0.53 & 27029 & 5.2 & 78 & 12.7 \\
\hline Canada & 0.84 & 29365 & 6.4 & 89 & 3.94 \\
\hline Czech Republic & 0.39 & 18404 & 4.1 & 92 & 6.98 \\
\hline Denmark & 0.53 & 26491 & 5.6 & 78 & 2.03 \\
\hline Finland & 0.47 & 27927 & 6.9 & 85 & 3.58 \\
\hline France & 0.60 & 28799 & 6.5 & 73 & 8.15 \\
\hline Germany & 0.54 & 31252 & 3.1 & 86 & 5.25 \\
\hline Greece & 0.80 & 18575 & 12.2 & 68 & 6.16 \\
\hline Hungary & 0.53 & 15442 & 5.7 & 82 & 3.19 \\
\hline Iceland & 0.50 & 23965 & 4.1 & 71 & 12.25 \\
\hline Ireland & 0.45 & 23917 & 5.9 & 75 & 4.2 \\
\hline Israel & 0.65 & 22104 & 5 & 85 & 16.03 \\
\hline Italy & 0.42 & 25166 & 5.9 & 57 & 3.66 \\
\hline Japan & 0.25 & 26111 & 2.4 & 94 & 22.26 \\
\hline South Korea & 0.72 & 19510 & 3.2 & 82 & 18.72 \\
\hline $\begin{array}{l}\text { The } \\
\text { Netherlands }\end{array}$ & 0.32 & 27888 & 4.5 & 73 & 0.45 \\
\hline New Zealand & 0.63 & 23815 & 5.1 & 74 & 13.87 \\
\hline Norway & 0.51 & 33492 & 3.1 & 82 & 2.82 \\
\hline Poland & 0.48 & 17852 & 7.3 & 90 & 7.41 \\
\hline Portugal & 0.54 & 20086 & 8.6 & 38 & 9.62 \\
\hline $\begin{array}{l}\text { Slovak } \\
\text { Republic }\end{array}$ & 0.50 & 17503 & 5.5 & 92 & 7.02 \\
\hline Spain & 0.78 & 22477 & 17.8 & 55 & 5.89 \\
\hline Sweden & 0.51 & 29185 & 6.5 & 88 & 1.13 \\
\hline Switzerland & 0.54 & 33491 & 3 & 86 & 6.72 \\
\hline Turkey & 0.47 & 14095 & 8.1 & 34 & 40.86 \\
\hline United States & 0.69 & 41335 & 5.9 & 89 & 11.3 \\
\hline
\end{tabular}

Table 2 shows the values of each variable for each OECD country

Source: authors' own elaboration from the GEM (2015) and OECD Better Life Index (OECD, 2015) 


\section{Results and Discussion}

As a first step, the application of the fuzzy QCA methodology requires the calibration of the variables, in order to indicate the degree of belonging to a well-defined and specified set. In this research, calibration indicates the extent to which countries can be considered members of sets that change according to their particular economic and social attributes. More specifically, there are 5 factors that are analysed, which give rise to the definition of sets: TEA ratio, work-life balance, education, income and jobs.

The values of median and percentiles were taken to round up, taking as calibration values the combination of values that best synthesizes or adjusts both the study sample and the existing and known theory.

compute: tearatiof $=$ calibrate $($ tearatio $, 0.85,0.45,0.15)$

compute: worklifebalancef $z=$ calibrate $($ worklifebalance $, 1,7,20)$

compute: educationfz $=$ calibrate $($ education $, 90,70,35)$

compute: incomefz $=$ calibrate $($ income $, 33000,26000,15000)$

compute: jobsfz $=$ calibrate $($ jobs, $3,6,12)$

Once results and all conditions have been calibrated (the suffix $f z$ indicates the calibrated variable), we proceed to extract the table of truth (Table 3) in which all possible configurations are listed (there are $2 \mathrm{~K}$ configurations or rows, where $\mathrm{k}$ is the Number of conditions, in this case $2^{4}=16$ combinations). In each configuration, value $=1$ indicates a score for the calibrated variable which can be greater than or equal to 0.5 (in other words, closer to the full member category) and value $=0$ indicates values of the calibrated variable less than 0.5 (in other words, closer to the no member category). Then, we ranked from highest to lowest the number of cases with a membership score greater than 0.5 for that configuration (column number is the cumulative \%) and, as we can check in the table of truth, the consistency of each of them is shown based on the subset relation to the result: 
Table 3. Table of truth

\begin{tabular}{|c|c|c|c|c|c|}
\hline worklifebalanfz & jobsfz & incomefz & educationfz & number tearatiofz & $\begin{array}{c}\text { Raw } \\
\text { consist. }\end{array}$ \\
\hline 1 & 1 & 1 & 1 & $6(22 \%)$ & 0.89169 \\
\hline 0 & 1 & 1 & 1 & $5(40 \%)$ & 0.93487 \\
\hline 0 & 1 & 0 & 1 & $4(55 \%)$ & 0.90764 \\
\hline 1 & 0 & 1 & 1 & $3(66 \%)$ & 0.96360 \\
\hline 1 & 1 & 0 & 1 & $2(74 \%)$ & 0.91694 \\
\hline 1 & 0 & 0 & 0 & $2(81 \%)$ & 0.96828 \\
\hline 0 & 0 & 0 & 0 & $2(88 \%)$ & 0.92127 \\
\hline 1 & 1 & 0 & 0 & $1(92 \%)$ & 0.91466 \\
\hline 0 & 0 & 1 & 1 & $1(96 \%)$ & 1.00000 \\
\hline 0 & 0 & 0 & 1 & $\begin{array}{l}1 \\
(100 \%)\end{array}$ & 0.98695 \\
\hline 1 & 1 & 1 & 0 & $\begin{array}{l}0 \\
(100 \%)\end{array}$ & \\
\hline 1 & 0 & 1 & 0 & $\begin{array}{l}0 \\
(100 \%)\end{array}$ & \\
\hline 1 & 0 & 0 & 1 & $\begin{array}{l}0 \\
(100 \%)\end{array}$ & \\
\hline 0 & 1 & 1 & 0 & $\begin{array}{l}0 \\
(100 \%)\end{array}$ & \\
\hline 0 & 1 & 0 & 0 & $\begin{array}{l}0 \\
(100 \%)\end{array}$ & \\
\hline 0 & 0 & 1 & 0 & $\begin{array}{l}0 \\
(100 \%)\end{array}$ & \\
\hline
\end{tabular}

Table 3 shows the results of the table of truth in which all possible configurations of variables are listed

Source: authors' own elaboration

In the second step, we deleted those configurations with no cases (reminders) or with a single case (the configurations that are maintained must cover $75-80 \%$ of cases, in this case it was $88 \%$ ). Then, we set a consistency threshold to distinguish causal combinations that are subsets of the result from those which are not. In general, values below 0.75 in this column indicate substantial inconsistency. 0.92 was selected as the consistency threshold and the value $=1$ was assigned to the result variable (tearatiofz) when the consistency of that configuration exceeded the 0.92 threshold, otherwise value $=0$ was assigned. Finally, as we can check in table 4 . 
Table 4. FsQCA output

\begin{tabular}{|c|c|c|c|c|c|c|}
\hline worklifebalanfz & jobsfz & incomefz & educationfz & number & tearatiofz & $\begin{array}{c}\text { Raw } \\
\text { consist. }\end{array}$ \\
\hline 1 & 1 & 1 & 1 & $6(22 \%)$ & 0 & 0.89169 \\
\hline 0 & 1 & 1 & 1 & $5(40 \%)$ & 1 & 0.93487 \\
\hline 0 & 1 & 0 & 1 & $4(55 \%)$ & 0 & 0.90764 \\
\hline 1 & 0 & 1 & 1 & $3(66 \%)$ & 1 & 0.96360 \\
\hline 1 & 1 & 0 & 1 & $2(74 \%)$ & 0 & 0.91694 \\
\hline 1 & 0 & 0 & 0 & $2(81 \%)$ & 1 & 0.96828 \\
\hline 0 & 0 & 0 & 0 & $2(88 \%)$ & 1 & 0.92127 \\
\hline
\end{tabular}

Table 4 shows the combinations which are subsets of the result from those which are not

Source: authors' own elaboration

The intermediate solution was obtained according to the procedure established by Ragin \& Sonnett (2004), it is formed by 3 combinations that increase the female entrepreneurship in a sufficient way (See Table 5):

Table 5. FsQCA output: Intermediate Solution. Reduced final set: Results in High Female Entrepreneurship

\begin{tabular}{|c|c|c|c|}
\hline Sets & $\begin{array}{l}\text { Raw } \\
\text { coverage }\end{array}$ & $\begin{array}{l}\text { Unique } \\
\text { coverage }\end{array}$ & Consistency \\
\hline >educationf $* \sim$ incomefz $*$ jobsfz & 0.3172 & 0.1165 & 0.8923 \\
\hline educationf $z *$ incomef $z *$ jobsf $z * \sim$ worklifebalanfz & 0.3747 & 0.1682 & 0.9348 \\
\hline educationf $z *$ incomef $z *$ jobsf $z^{*}$ worklifebalanfz & 0.3225 & 0.0771 & 0.9636 \\
\hline $\begin{array}{l}\text { solution coverage: } 0.6177 \\
\text { solution consistency: } 0.8897\end{array}$ & & & \\
\hline
\end{tabular}

Table 5 shows the Intermediate Solutions, the three combinations that increase the female entrepreneurship in a sufficient way

Source: authors' own elaboration

Final solution can be expressed as follows:

\section{educationfz* incomefz* jobsfz + educationfz*incomefz*jobsfz* $\sim$ worklifebalanfz + educationf $z^{*}$ incomefz* ${ }^{*}$ jobsf $z^{*}$ worklifebalanf $z$}

In these combinations the three most usual logical operations in fuzzy sets are represented in the following way: negation $(\sim)$; the intersection (and) is represented by a multiplier operator $(*)$; and the Union (or) is represented by an additional operator $(+)$. 
The 3 solutions shown in table 5 increase female entrepreneurship in a sufficient way in $89 \%$ of the cases and cover $62 \%$ of the cases: a high probability of unemployment, that is to say: a low sustainable household income and a low incidence of higher education (solution 1); or a low probability of unemployment, high sustainable household income and a high incidence of higher education, but with a high percentage of overexposed workers (very long working hours) (solution 2); or a high probability of unemployment, high sustainable household income and a high incidence of higher education; but with a low percentage of overexposed workers (solution 3); leads to increase female entrepreneurship in a sufficient way . ).

Each combination shows a degree of coverage between $30 \%$ and $40 \%$. The Unique coverage (the one exclusive to a single combination) allows the identification of the most important combinations, and it can be checked that educationfz*incomefz $*$ jobsfz* $\sim$ worklifebalanfz covers $17 \%$ of cases individually (of total coverage, $62 \%$ Coverage).

It is interesting to identify those countries that fulfil the conditions and whether they are consistent or not with the result. To this end, each country was defined by two coordinates $(\mathrm{X}, \mathrm{Y})$ : the first $(\mathrm{X})$ represents the degree of membership in each combination and the second $(\mathrm{Y})$ represents the degree of belonging to the result (high female entrepreneurship). Countries that meet a condition are those whose first coordinate $(\mathrm{X})$ is greater than 0.5 . Within them, consistent and inconsistent countries can be found. The consistent ones are those countries whose second coordinate value $(\mathrm{Y})$ is greater than the first one $(\mathrm{X})$; therefore, the inconsistent ones are those whose first value $(\mathrm{x})$ is greater than the second $(\mathrm{Y})$.

In order to represent the consistency and coverage of a solution, scatter plots that address the solution with the result can be used: a combination - a set - that systematically has all (calibrated) scores less than or equal to the result scores (upper triangle) means that it represents a subset of the result and that consistency is high $(\mathrm{X}<=\mathrm{Y})$. The countries below the diagonal are inconsistent $(\mathrm{X}>\mathrm{Y})$ with the result and those above are the consistent ones $(\mathrm{X}<=\mathrm{Y})$.

However, within each group there are degrees of relevance depending on whether the membership score to the combinations is less than or greater than 0.5 (upper right quadrant): e.g. an inconsistency in the lower triangle $(\mathrm{X}>=0.5, \mathrm{X}>\mathrm{Y})$ is more critical, and a consistency in the upper triangle $(\mathrm{X}>=0.5, \mathrm{X}<=\mathrm{Y})$ is more relevant. 
Thus, as shown in figure 1 , Spain $(0.72,0.92)$ and Greece $(0.54,0.93)$ would be the most consistent countries with solution 1 and would define the group. Only three countries are inconsistent, where Portugal $(0.79,0.58)$ is the most inconsistent one (in the lower triangle).

\section{Figure 1. Solution 1}

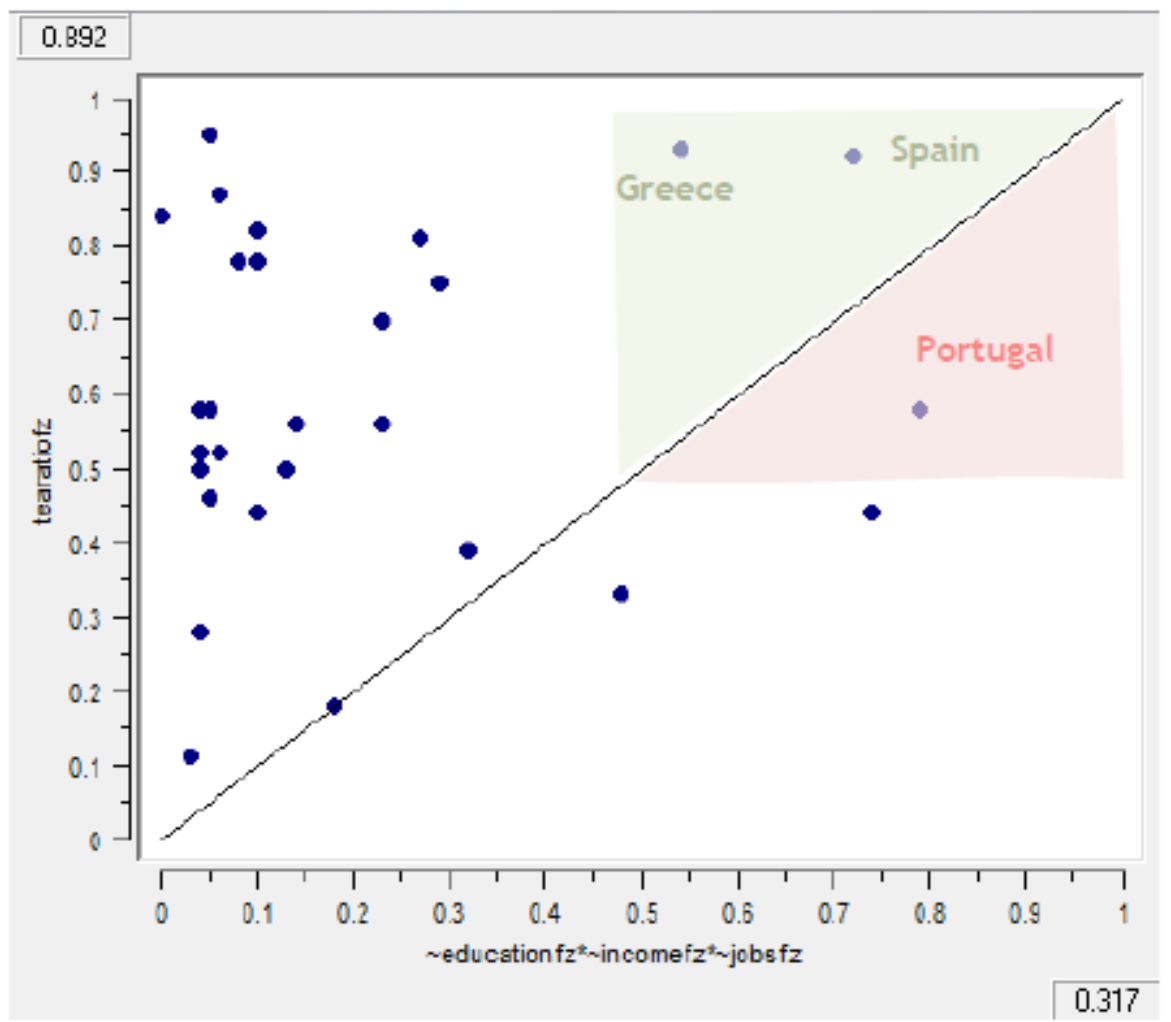

Source: authors' own elaboration

With respect to solution 2 represented in FIGURE 2, Australia $(0.71,0.78)$, Austria $(0.54,0.82)$ and the United States $(0.52,0.84)$, would be the most relevant and would define the group, while Great Britain $(0.61,0.56)$, in the lower triangle, would be the most inconsistent one, although it is very close to the diagonal. 
Figure 2. Solution 2

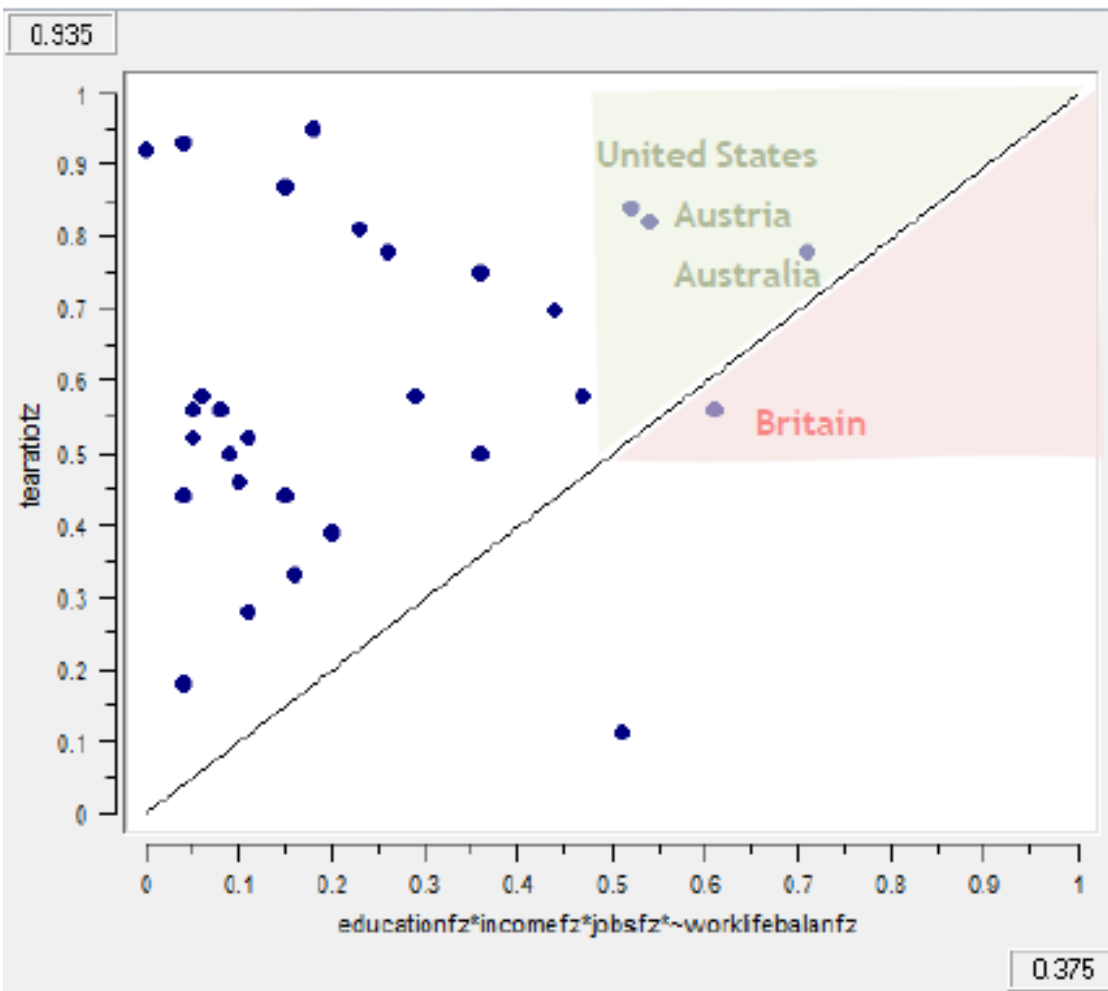

Source: authors' own elaboration

It should be noted that Portugal and Great Britain may intuitively appear as defining countries in previous solutions, because they have 2 coordinates greater than 0.5 (they fulfil the condition and have high female entrepreneurship), but do not meet the consistency condition since the first coordinate is greater than the second one. However, Great Britain presents such a close difference between its coordinates that it can be considered a minor case of inconsistency.

Regarding solution 3 (Figure 3), Canada (0.55.0.95) is the most consistent country and defines the group. There are only 2 inconsistent countries, where Sweden $(0.56,0.52)$ is the most inconsistent one (located in the lower triangle), however since it is so close to the diagonal it can represent a minor case of inconsistency. Similarly, since the Y coordinate of Finland (0.61.0.44) is so close to the 0.5 value, it suggests that this country shows a tendency towards high female entrepreneurship. 


\section{Figure 3. Solution 3}

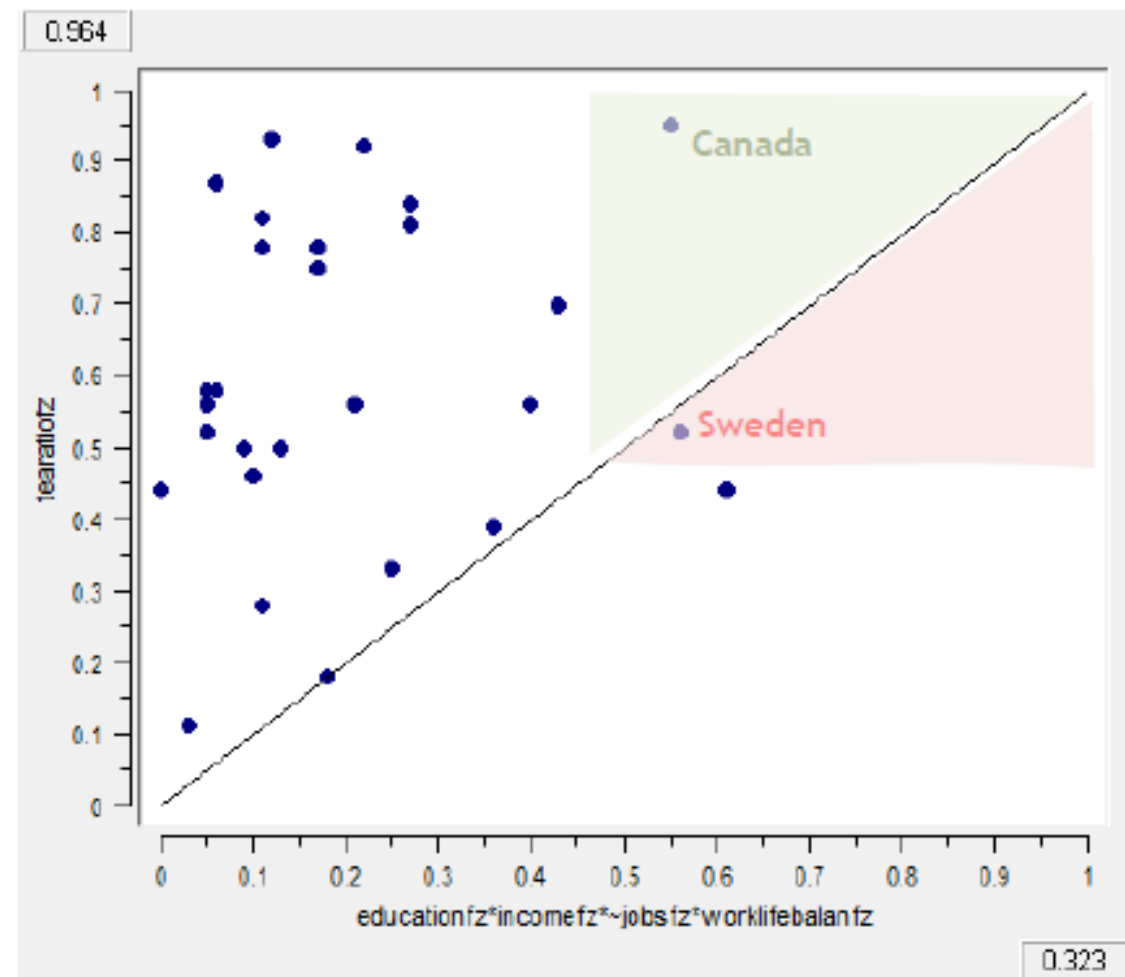

Source: authors' own elaboration

With regard to the countries that have defined a group in each one of the three combinations that lead to high female entrepreneurship, it is worth nothing the different weights we can find for each one of the two main entrepreneurship motivations: necessity or opportunity. As it can be seen in Table 6, although in most cases entrepreneurship is generated by opportunity, in the most relevant countries of solution 1 (Greece and Spain), the percentage of entrepreneurship by necessity is higher than those representing solutions 2 and 3 .

Table 6. Entrepreneurship motivation

\begin{tabular}{|l|l|l|}
\hline $\begin{array}{c}\text { Country } \\
\text { name }\end{array}$ & \multicolumn{1}{c|}{$\begin{array}{c}\text { TEA } \\
\text { necessity }\end{array}$} & $\begin{array}{c}\text { TEA } \\
\text { opportunity }\end{array}$ \\
\hline Australia & 12.7 & 85.1 \\
\hline Austria & 15.6 & 79.4 \\
\hline Canada & 13.5 & 81.1 \\
\hline Greece & 22.3 & 75.4 \\
\hline Spain & 24.8 & 73.5 \\
\hline $\begin{array}{l}\text { United } \\
\text { States }\end{array}$ & 14.3 & 82.2 \\
\hline
\end{tabular}


Table 6 shows the cases in which entrepreneurship is generated by opportunity and the cases in which entrepreneurship is generated by necessity

Source: authors' own elaboration from the GEM (2015)

Since the FsQCA technique is not symmetric - unlike other quantitative estimation techniques - it is convenient to study which combinations of factors lead to low female entrepreneurship, since a result not always explains its negation. Table 7 shows the resulting configuration for the negative result:

Table 7. FsQCA output: Intermediate Solution. Reduced Final Set: Results in Low Female Entrepreneurship

\begin{tabular}{|l|l|l|l|}
\hline Sets & $\begin{array}{l}\text { Raw } \\
\text { coverage }\end{array}$ & $\begin{array}{l}\text { Unique } \\
\text { coverage }\end{array}$ & Consistency \\
\hline educationfz*incomefz jobsfz*worklifebalanfz & 0.4710 & 0.4710 & 0.9389 \\
\hline solution coverage: 0.4710 & & & \\
solution consistency: 0.9389 & & & \\
\hline \multicolumn{2}{|l|}{} & & \\
\hline
\end{tabular}

result.

Source: authors' own elaboration

With a $47 \%$ coverage and a consistency of $93 \%$, the combination of a high work-personal balance, low probability of unemployment, high incidence of higher education and low sustainable expenditure leads sufficiently to low female entrepreneurship.

Ireland $(0.52,0.61)$ is the most representative country of this solution, although Hungary $(0.57,0.44)$ with a value of 0.44 would be close to being considered in terms of low level of female entrepreneurship.

\section{Conclusions}

The objective of this work has been to study the relationship between the entrepreneurial activity and both the gender and the welfare conditions of a country. To this end, the TEA ratio has been used as a measure of female entrepreneurship in a country. As a measure of wellbeing, four indicators of the Better Life Index (OECD, 2015) have been chosen: work-life balance, educational attainment, sustainable household income 
and job security; since all these indicators are directly related to the wellbeing of a country. Four hypotheses have been established analyzing the relationship of those wellbeing indicators with female entrepreneurship.

The empirical study has focused on 29 OECD countries covering different geographic regions (Western Europe, Eastern and Central Europe, Middle East, etc.). Since the sample is relatively small, it is essential to employ a selective approach when choosing causal conditions, with the FsQCA methodology being the most appropriate for small samples, as the one analyzed in the present study. Consequently, a total of five variables were used: one outcome (tearatio) and four antecedent conditions (work-life balance, education attainment, income and job security).

From our study, it can be withdrawn that countries with high probability of unemployment, low sustaianble household incomes and low incidence of higher education, the balance or imbalance between work and personal life (\% of overexposed workers, i.e. very long working hours) are not relevant for high female entrepreneurship.

In addition, countries with high sustainable household incomes and high level of higher education achieves high female entrepreneurship with both, a good work-life balance (despite of a high unemployment probability), and a high labour-personal imbalance (in this latter, with a low probability of unemployment).

On the other hand, it is noteworthy that if the union of education and work-personal balance is combined with high incomes and a high probability of unemployment, it will lead to high female entrepreneurship. However, if this binomial turns intothe opposite combination (low incomes and low probability of unemployment), then, it leads to low female entrepreneurship

Finally, countries have been classified according to entrepreneurship motivations, opportunity or necessity, from our study it can be withdrawn that neither the job security, nor the work-life balance are relevant to mark the difference between the two aforementioned motivations. However, sustainable household income and higher education are relevant when differentiating between opportunity and necessity motivations. Thus, the higher TEA necessity percentage occurs in those countries having low sustainable household incomes and low higher education level; as it happens in Spain and Greece. This percentage lowers in countries with higher levels of higher education and sustainable household incomes; as it is the case of Austria, Australia, United States and Canada. 
The main implications of our study can serve as guidance to the governments of the OECD countries that wish to promote quality female entrepreneurship, whose origin is the so-called opportunity-based entrepreneurship. These countries should pay special attention to the improvement of higher education, increasing the population that accesses these levels jointly with a good preparation to create businesses with greater added value.

Other possible government actions in line with promoting quality entrepreneurship could be aimed at improving the sustainable income of households (Household income). In this way, one could act straight on incomes by increasing them through public subsidies aimed at these potential entrepreneurs or with a tax and social security policy in favour of these entrepreneurs.

As a future line of research, this analysis could be carried out in countries that do not belong to the OECD, e.g. some emerging countries, where entrepreneurship driven by necessity is greater than entrepreneurship driven by opportunity, and in which different results will probably be obtained regarding the motives of the venture such as the unemployment rate, for example.

\section{References}

Ahl, H., \& Nelson, T. (2015). How policy positions women entrepreneurs: A comparative analysis of state discourse in Sweden and the United States. Journal of Business Venturing, 30(2), 273-291. https://doi.org/10.1016/j.jbusvent.2014.08.002

Andersson, P. (2008). Happiness and health: Wellbeing among the self-employed. Journal of SocioEconomics, 37(1), 213-236. https://doi.org/10.1016/j.socec.2007.03.003

Bardasi, E., Sabarwal, S., \& Terrell, K. (2011). How do female entrepreneurs perform? Evidence from three developing regions. Small Business Economics, 37(4), 417-441. https://doi.org/10.1007/s11187-011-9374-z

Bergheim, S., Schneider, S., Giesel, B., \& Walter, N. (2006). Measures of wellbeing. There is more to it than GDP. Deutsche Bank Research, Frankfurt

Berglund, H. (2015). Between cognition and discourse: phenomenology and the study of entrepreneurship. International Journal of Entrepreneurial Behaviour \& Research, 21(3), 472-488. https://doi.org/http://dx.doi.org/10.1108/IJEBR-12-2013-0210

Bianchi, M., Parisi, V., \& Salvatore, R. (2016). Female entrepreneurs: motivations and constraints. An Italian regional study. International Journal of Gender and Entrepreneurship, 8(3), 198-220. https://doi.org/10.1108/IJGE-08-2015-0029

Bittencourt Marconatto, D. A., Barin-Cruz, L., Pozzebon, M., \& Poitras, J. E. (2016). Developing sustainable business models within BOP contexts: Mobilizing native capability to cope with government programs. Journal of Cleaner Production, 129, 735-748. 
https://doi.org/10.1016/j.jclepro.2016.03.038

Boarini, R., Comola, M., Smith, C., Manchin, R., \& Keulenaer, F. de. (2012). What Makes for a Better Life?: The determinants of subjective well-being in OECD countries-Evidence from the Gallup World Poll. OECD Statistics Working Papers, 2012(3), O_1. 2012. https://doi.org/10.1787/5k9b9ltjm937-en

Boarini, R., \& D'Ercole, M. M. (2013). Going beyond GDP: An OECD Perspective. Fiscal Studies, 34(3), 289-314. https://doi.org/10.1111/j.1475-5890.2013.12007.x

Bradshaw, J., Hoelscher, P., \& Richardson, D. (2007). “Comparing child wellbeing in OECD countries: concepts and methods".

Brindley, C. (2005). Barriers to women achieving their entrepreneurial potential. International Journal of Entrepreneurial Behavior \& Research. Emerald Group Publishing Limited. Retrieved from http://www.emeraldinsight.com/doi/full/10.1108/13552550510590554

Burke, A. E., Fitzroy, F. R., \& Nolan, M. A. (2008). What makes a die-hard entrepreneur? beyond the “employee or entrepreneur" dichotomy. Small Business Economics, 31(2), 93-115. https://doi.org/10.1007/s11187-007-9086-6

Buttner, H. E., \& Moore, D. P. (1997). Women's organizational exodus to entrepreneurship: Self-reported motivations and correlates with success. Journal of Small Business Management, 35(1), 34-46. Retrieved from http://search.ebscohost.com

Carter, S. (2011). The rewards of entrepreneurship:Exploring the incomes, wealth, and economic wellbeing of entrepreneurial households". Entrepreneurship Theory and Practice. 35(1), 39-55

Castaño, M.-S., Méndez, M.-T., \& Galindo, M.Á. (2015). The effect of social, cultural, and economic factors on entrepreneurship. Journal of Business Research, 68(7), 1496-1500. https://doi.org/10.1016/j.jbusres.2015.01.040

Castellano, R., Musella, G., \& Punzo, G. (2017). Structure of the labour market and wage inequality: evidence from European countries. Quality \& Quantity, 51(5), 2191-2218.

Cervelló-Royo, R., Moya-Clemente, I., \& Ribes-Giner, G. (2015). Microfinance Institutions (MFIs) in Latin America: Who Should Finance the Entrepreneurial Ventures of the Less Privileged?. In New Challenges in Entrepreneurship and Finance (pp. 235-245). Springer, Cham.

Cervelló-Royo, R., Guijarro, F., \& Martinez-Gomez, V. (2017). Social Performance considered within the global performance of Microfinance Institutions: a new approach. Operational Research, 1-19. (In press) DOI: 10.1007/s12351-017-0360-3

Chaaban, J., Irani, A., \& Khoury, A. (2016). The Composite Global Wellbeing Index (CGWBI): A New Multi-Dimensional Measure of Human Development. Social Indicators Research, 129(1), 465-487. https://doi.org/10.1007/s11205-015-1112-5

Chapple, S. (2009). Child wellbeing and sole-parent family structure in the OECD: An analysis. OECD”. Social, Employment, and Migration Working Papers, (82), 0_1.

Christofides, L. N., Polycarpou, A., \& Vrachimis, K. (2013). Gender wage gaps, "sticky floors" and "glass ceilings" in Europe. Labour Economics, 21, 86-102.

https://doi.org/10.1016/j.labeco.2013.01.003

Cumming, D., Hou, W., \& Lee, E. (2016). Sustainable and Ethical Entrepreneurship, Corporate Finance and Governance, and Institutional Reform in China. Journal of Business Ethics, 134(4), 505-508. https://doi.org/10.1007/s10551-014-2381-7

Cummins, R. A., Eckersley, R., Pallant, J., Van Vugt, J., \& Misajon, R. (2003). Developing a national index of subjective wellbeing: The Australian Unity Wellbeing Index. Social Indicators Research, 64(2), 159-190. https://doi.org/10.1023/A:1024704320683 
De la Cruz Sánchez-Escobedo, M., Díaz-Casero, J. C., Díaz-Aunión, Á. M., \& Hernández-Mogollón, R. (2014). Gender analysis of entrepreneurial intentions as a function of economic development across three groups of countries. International Entrepreneurship and Management Journal, 10(4), 747765. https://doi.org/10.1007/s11365-014-0314-7

Devece, C., Peris-Ortiz, M., \& Rueda-Armengot, C. 2016. Entrepreneurship during economic crisis: Success factors and paths to failure. Journal of Business Research, pp. 5366-5370. https://doi.org/10.1016/j.jbusres.2016.04.139

Diener, E. (2009). Subjective Wellbeing. In The sicence of Wellbeing (pp. 11-58). Springer, Dordrecht. https://doi.org/10.1007/978-90-481-2350-6_2

Dodge, R., Daly, A., Huyton, J., \& Sanders, L. (2012). The challenge of defining wellbeing. International Journal of Wellbeing, 2(3), 222-235. https://doi.org/10.5502/ijw.v2i3.4

Fiss, P. C. (2011). Building better casual theories: A fuzzy set approach to typologies in organization research. Academy of Management Journal, 54(2), 393-420

Fleche, S., Smith, C., \& Sorsa, P. (2012). Exploring Determinants of Subjective Wellbeing in OECD Countries EVIDENCE FROM THE WORLD VALUE SURVEY. Working Papers, OECD Statistics, (2012). https://doi.org/10.1787/5kg0k6zlcm5k-en

Foley, A. \& Griffith, B. (1998). Education, training and the promotion of high quality entrepreneurs in the Republic of Ireland. Educating entrepreneurs for wealth creation. Aldershot: Ashgate.

Garikipati, S. (2012). Microcredit and Women's Empowerment: Through the Lens of Time-Use Data from Rural India. Development and Change, 43(3), 719-750. https://doi.org/10.1111/j.14677660.2012.01780.x

GEM Global Entrepreneurship Monitor (2015).Global Report.

Harter, J. K., Schmidt, F. L., \& Keyes, C. L. M. (2003). Wellbeing in the workplace and its relationship to business outcomes. A review of the Gallup studies. In Flourishing: The Positive Person and the Good Life (pp. 205-224). American Psychologi cal Association.

Henry, C., Foss, L., \& Ahl, H. (2015). Gender and Entrepreneurship Research: A review of methodological approaches. International Small Business Journal, 34(3), 217-241. https://doi.org/10.1177/0266242614549779

Hessels, J., Van Gelderen, M., \& Thurik, R. (2008). Entrepreneurial aspirations, motivations, and their drivers". Small Business Economics, 31(3), 323-339. https://doi.org/10.1007/s11187-008-9134-X

Iezzi, D. F., \& Deriu, F. (2014). Women active citizenship and wellbeing: the Italian case. Quality \& Quantity, 48(2), 845-862.

Jansson, T. (2017). Housing choices and labor income risk. Journal of Urban Economics, 99, 107-119. https://doi.org/10.1016/j.jue.2016.12.006

Johansen, V., \& Foss, L. (2013). The effects of entrepreneurship education - Does gender matter? International Journal of Entrepreneurship and Small Business, 20(3), 255-271. https://doi.org/10.1504/IJESB.2013.056889

Judge, W. Q., Hu, H. W., Gabrielsson, J., Talaulicar, T., Witt, M. A., Zattoni, A., \& Kibler, B. (2015). Configurations of capacity for change in entrepreneurial threshold firms: Imprinting and strategic choice perspectives. Journal of Management Studies, 52(4), 506-530. https://doi.org/10.1111/joms.12121

Kautonen, T., Kibler, E., \& Minniti, M. (2017). Late-career entrepreneurship, income and quality of life". Journal of Business Venturing, 32(3), 318-333. https://doi.org/10.1016/j.jbusvent.2017.02.005

Kephart, P., \& Schumacher, L. (2005). Has the "Glass Ceiling” Cracked? An Exploration of Women Entrepreneurship. Journal of Leadership \&amp; Organizational Studies, 12(1), 2-15. 
https://doi.org/10.1177/107179190501200102

Kirkwood, J. (2009). Motivational factors in a push-pull theory of entrepreneurship. Gender in Management: An International Journal, 24(5), 346-364.

https://doi.org/10.1108/17542410910968805

Kobeissi, N. (2010). Gender factors and female entrepreneurship: International evidence and policy implications. Journal of International Entrepreneurship, 8, 1-35. Retrieved from http://link.springer.com/article/10.1007/s10843-010-0045-y

Kuckertz, A., Berger, E. S. C., \& Allmendinger, M. P. (2015). What drives entrepreneurship? A configurational analysis of the determinants of entrepreneurship in innovation-driven economies. Die Betriebswirtschaft/Business Administration Review, 75(4), 273-288. https://doi.org/10.1017/CBO9781107415324.004

La Placa, V., McNaught, A., \& Knight, A. (2013). Discourse on wellbeing in research and practice. International Journal of Wellbeing, 3, 116-125. https://doi.org/10.5502/ijw.v3i1.7

Langowitz, N., \& Minniti, M. (2007). The Entrepreneurial Propensity of Women. Entrepreneurship Theory and Practice, 31(3), 341-364. https://doi.org/10.1111/j.1540-6520.2007.00177.x

Lee, S. S. Y. (2013). Examining policy configurations as conditions for long-term unemployment and non-standard employment in OECD countries using fuzzy-set analysis. Quality \& Quantity, 47(6), 3521-3536.

Leffler, E. \& Svedberg, G. (2005). Enterprise Learning: a challenge to education?. European Educational Research Journal, 4(3), 219-227

Levie, J., \& Autio, E. (2008). A theoretical grounding and test of the GEM model. Small Business Economics, 31(3), 235-263. https://doi.org/10.1007/s11187-008-9136-8

Maccagnan, A., Wren-Lewis, S., Brown, H., \& Taylor, T. (2016). Wellbeing and Society: Towards Quantification of the Co-benefits of Wellbeing. Social Indicators Research [In press].

Mandl, C., Berger, E. S. C., \& Kuckertz, A. (2016). Do you plead guilty? Exploring entrepreneurs' sensemaking-behavior link after business failure. Journal of Business Venturing Insights, 5, 9-13. https://doi.org/10.1016/j.jbvi.2015.12.002

Martin, B. C., McNally, J. J., \& Kay, M. J. (2013). Examining the formation of human capital in entrepreneurship: A meta-analysis of entrepreneurship education outcomes. Journal of Business Venturing, 28(2), 211-224. https://doi.org/10.1016/j.jbusvent.2012.03.002

McClelland, E., Swail, J., Bell, J., \& Ibbotson, P. (2005). Following the pathway of female entrepreneurs. International Journal of Entrepreneurial Behavior \& Research, 11(2), 84-107. https://doi.org/10.1108/13552550510590527

Millán, J. M., Hessels, J., Thurik, R., \& Aguado, R. (2013). Determinants of job satisfaction: A European comparison of self-employed and paid employees. Small Business Economics, 40(3), 651-670. https://doi.org/10.1007/s11187-011-9380-1

Minniti, M., \& Nardone, C. (2007). Being in someone else's shoes: The role of gender in nascent entrepreneurship, 28(2-3), 223-238. https://doi.org/10.1007/s11187-006-9017-y

Mishra, V., Nielsen, I., \& Smyth, R. (2014). How does relative income and variations in short-run wellbeing affect wellbeing in the long run? Empirical evidence from China's Korean minority Social Indicators Research, 115(1), 67-91.

Murias, P., Martinez, F., \& de Miguel, C. (2006). An economic wellbeing index for the Spanish provinces: A Data Envelopment Analysis approach. Social Indicators Research, 77(3), 395-417. https://doi.org/10.1007/s11205-005-2613-4

Naudé, W. Amorós, J. E., \& Cisti, O. (2014). Surfeiting, the appetite may sticken: entrepreneurship and 
happiness. Small Business Economics, 42(3), 523-540.

Ng, T. W. H., \& Feldman, D. C. (2009). Re-examining the relationship between age and voluntary turnover. Journal of Vocational Behavior, 74(3), 283-294. https://doi.org/10.1016/j.jvb.2009.01.004

O’Connor, A. (2013). A conceptual framework for entrepreneurship education policy: Meeting government and economic purposes. Journal of Business Venturing, 28(4), 546-563. https://doi.org/10.1016/j.jbusvent.2012.07.003

Organization for Economic Cooperation and Development. (2015). "How's life?: Measuring wellbeing". Available at http://www.oecdbetterlifeindex.org

Orlova, L. V., Sakhabieva, G. A., Vasyaycheva, V. A., \& Pronina, N. N. (2016). Impact of educational attainment on the development of female entrepreneurship in Kazakhstan. Indian Journal of Science and Technology, 9(11). https://doi.org/10.17485/ijst/2016/v9i11/89427

Osberg, L., \& Sharpe, A. (2002). An Index of Economic Wellbeing for Selected OECD Countries. Review of Income and Wealth, 5(3), 291-316. https://doi.org/doi:10.1111/1475-4991.00056

Osberg, L., \& Sharpe, A. (2009). New estimates of the index of economic wellbeing for selected OECD countries, 1980-2007. Centre for the Study of Living Standards.

Parasuraman, S., Purohit, Y. S., Godshalk, V. M., \& Beutell, N. J. (1996). Work and Family Variables, Entrepreneurial Career Success, and Psychological Wellbeing. Journal of Vocational Behavior, 48(3), 275-300. https://doi.org/10.1006/jvbe.1996.0025

Patrick, C., Stephens, H., \& Weinstein, A. (2016). Where are all the self-employed women? Push and pull factors influencing female labor market decisions. Small Business Economics, 46(3), 365-390. https://doi.org/10.1007/s11187-015-9697-2

Poggesi, S., Mari, M., \& De Vita, L. (2015). What's new in female entrepreneurship research? Answers from the literature. International Entrepreneurship and Management Journal, 12(3), 735-764. https://doi.org/10.1007/s11365-015-0364-5

Ragin, C. (1987) The Comparative Method: Moving Beyond Qualitative and Quantitative Strategies. University of California Press, Berkeley

Ragin, C. C. (1989). New directions in comparative research. Cross-National Research in Sociology, $57-$ 76.

Ragin, C. C. (2000). Fuzzy-set social science. Chicago: University of Chicago Press.

Ragin Charles C. \& Sonnett J. (2004). Between Complexity and Parsimony: Limited Diversity, Counterfactual Cases, and Comparative Analysis. In Charles C. Ragin, ed., Redesigning Social Inquiry. University of Chicago Press.

Ragin, C. C. (2008). Redesigning social inquiry: Fuzzy sets and beyond (Vol 240). Chicago: University of Chicago Pres.

Rahman, S. A., Amran, A., Ahmad, N. H., \& Taghizadeh, S. K. (2016). Enhancing the Wellbeing of Base of the Pyramid Entrepreneurs through Business Success: The Role of Private Organizations. Social Indicators Research, 127(1), 195-216. https://doi.org/10.1007/s11205-015-0951-4

Renee Baptiste, N. (2008). Tightening the link between employee wellbeing at work and performance. Management Decision, 46(2), 284-309. https://doi.org/10.1108/00251740810854168

Rey-Martí, A., Tur Porcar, A., \& Mas-Tur, A. (2015). Linking female entrepreneurs' motivation to business survival. Journal of Business Research, 68(4), 810-814. https://doi.org/10.1016/j.jbusres.2014.11.033

Reynolds, P. D., Bygrave, W. D., Autio, E., Cox, L. W., \& Hay, M. (2002). Global Entrepreneurship 
Monitor, 2002 Executive Report. London.

Ribes-Giner, G., Moya-Clemente, I., Cervelló-Royo, R., \& Perello-Marin, M. R. (2018). Domestic economic and social conditions empowering female entrepreneurship. Journal of Business Research, 89, 182-189.

Ruth Eikhof, D., Summers, J., Carter, S., Eikhof, D. R., Summers, J., \& Carter, S. (2013). Women doing their own thing": media representations of female entrepreneurship. International Journal of Entrepreneurial Behavior \& Research, 19(5), 547-564. https://doi.org/10.1108/IJEBR-09-20110107

Sampedro Gallego, R., \& Camarero Rioja, L. (2007). Female entrepreneurs in rural Spain - The failed subject of development. Revista Internacional de Sociología, 65(48), 121-146.

Saridakis, G., Marlow, S., \& Storey, D. J. (2014). Do different factors explain male and female selfemployment rates? Journal of Business Venturing, 29(3), 345-362. https://doi.org/10.1016/j.jbusvent.2013.04.004

Shepherd, D. A., Douglas, E. J., \& Shanley, M. (2000). New venture survival: Ignorance, external shocks, and risk reduction strategies. Journal of Business Venturing, 15(5), 393-410. https://doi.org/10.1016/S0883-9026(98)00008-1

Shepherd, D., \& Haynie, J. M. (2009). Birds of a feather don't always flock together: Identity management in entrepreneurship. Journal of Business Venturing, 24(4), 316-337. https://doi.org/10.1016/j.jbusvent.2007.10.005

Shinnar, R. S., Hsu, D. K., \& Powell, B. C. (2014). Self-efficacy, entrepreneurial intentions, and gender: Assessing the impact of entrepreneurship education longitudinally. The International Journal of Management Education, 12(3), 561-570. https://doi.org/10.1016/j.ijme.2014.09.005

Shir, N. (2015). Entrepreneurial Wellbeing: The Payoff Structure of Business Creation. Stockholm School of Economics.

Thiem, A., \& Dusa, A. (2013). QCA: A package for qualitative comparative analysis. R Package Version 2.0. The R Journal, 5, 87-97. Retrieved from https://cran.rproject.org/web/packages/QCA/index.html

Torri, M. M. C., \& Martinez, A. (2014). Women's empowerment and micro-entrepreneurship in India: Constructing a new development paradigm? Progress in Development Studies, 14(1), 31-48. https://doi.org/10.1177/1464993413504347

Tur-Porcar, A., Mas-Tur, A., \& Belso, J. A. (2017). Barriers to women entrepreneurship. Different methods, different results?. Quality \& Quantity, 51(5), 2019-2034.

Uy, M. A., Foo, M. Der, \& Song, Z. (2013). Joint effects of prior start-up experience and coping strategies on entrepreneurs' psychological wellbeing. Journal of Business Venturing, 28(5), 583597. https://doi.org/10.1016/j.jbusvent.2012.04.003

Uy, M. A., Sun, S., \& Foo, M. Der. (2017). Affect spin, entrepreneurs' wellbeing, and venture goal progress: The moderating role of goal orientation. Journal of Business Venturing, 32(4), 443-460. https://doi.org/10.1016/j.jbusvent.2016.12.001

Van der Sluis, J., Van Praag, M. \& Vijverberg, W. (2008). Education and entrepreneurship selection and performance: A review of empirical literature. Journal of economic surveys, 22(5), 795-841.

Verheul, I., Stel, A. Van, \& Thurik, R. (2006). Explaining female and male entrepreneurship at the country level (Vol. 18). https://doi.org/10.1080/08985620500532053

Witbooi, M., \& Ukpere, W. (2011). Indigenous female entrepreneurship: Analytical study on access to finance for women entrepreneurs in South Africa. African Journal of Business Management, 5(14), 5646-5657. 
Woodside, A. G., Bernal, P. M., \& Coduras, A. (2015). The general theory of culture, entrepreneurship, innovation, and quality-of-life: Comparing nurturing versus thwarting enterprise start-ups in BRIC, Denmark, Germany, and the United States. Industrial Marketing Management. https://doi.org/10.1016/j.indmarman.2015.11.003 